\section{BUKU AJAR HUKUM ADMINISTRASI NEGARA}

Hukum Administrasi Negara adalah peraturan-peraturan yang mengatur tentang bagaimana aparatur pemerintah dalam melaksanakan tugas-tugas Negara baik aparatur pemerintah pusat maupun pemerintah daerah dalam melaksanakan pelayanan dalam masyarakat.

Dalam buku ini mengupas tentang pengertian administrasi, Administrasi Negara, Hukum Administrasi Negara, Subyek Hukum Administrasi Negara, Sumber Hukum Administrasi negara, Asas Hukum Pemerintahan yang Baik, Hak dan Kewajiban Warga Negara dan Aparatur Pemerintah, Peradilan Tata Usaha Negara dan Konseptual Kebijakan Publik.

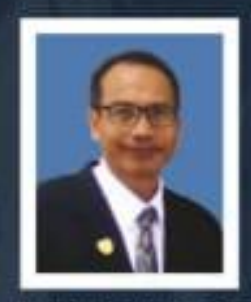

\section{Fakhruddin Razy, SH., MH}

Penulis lahir 21 Juni 1971 di Kecamatan Daha Utara Kabupaten Hulu Sungai Selatan Kalimantan Selatan, menyelesaikan pendidikan Sekolah Dasar Tahun 1984, Sekolah Menengah Pertama Tahun 1987, Sekolah Menengah Atas 1990, S1 Hukum Tahun 2000 di Sekolah Tinggi IImu Hukum Sultas Adam Banjarmasin dan S2 Hukum tahun 2016 di Fakultas Hukum Universitas Lambung Mangkurat. Dalam keseharian penulis bekerja sebagai dosen tetap Program Studi Hukum Fakultas Humaniora Universitas Sari Mulia.

\section{BUKU AJAR}

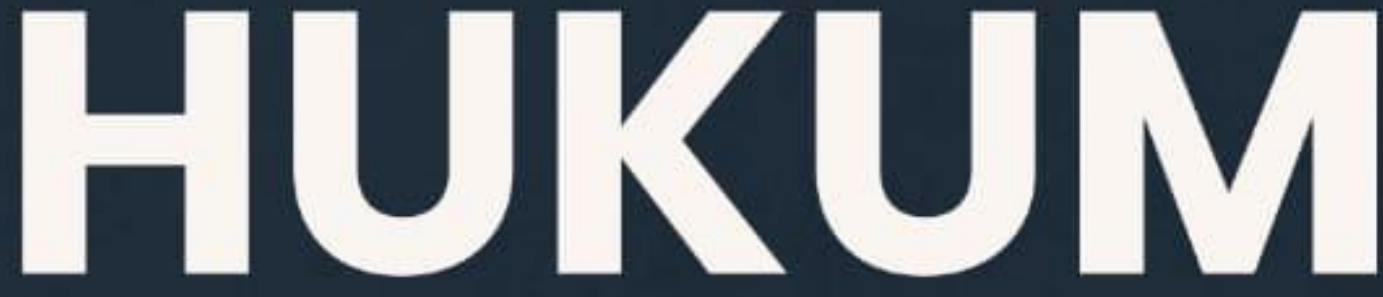
ADMINISTRASI NEGARA

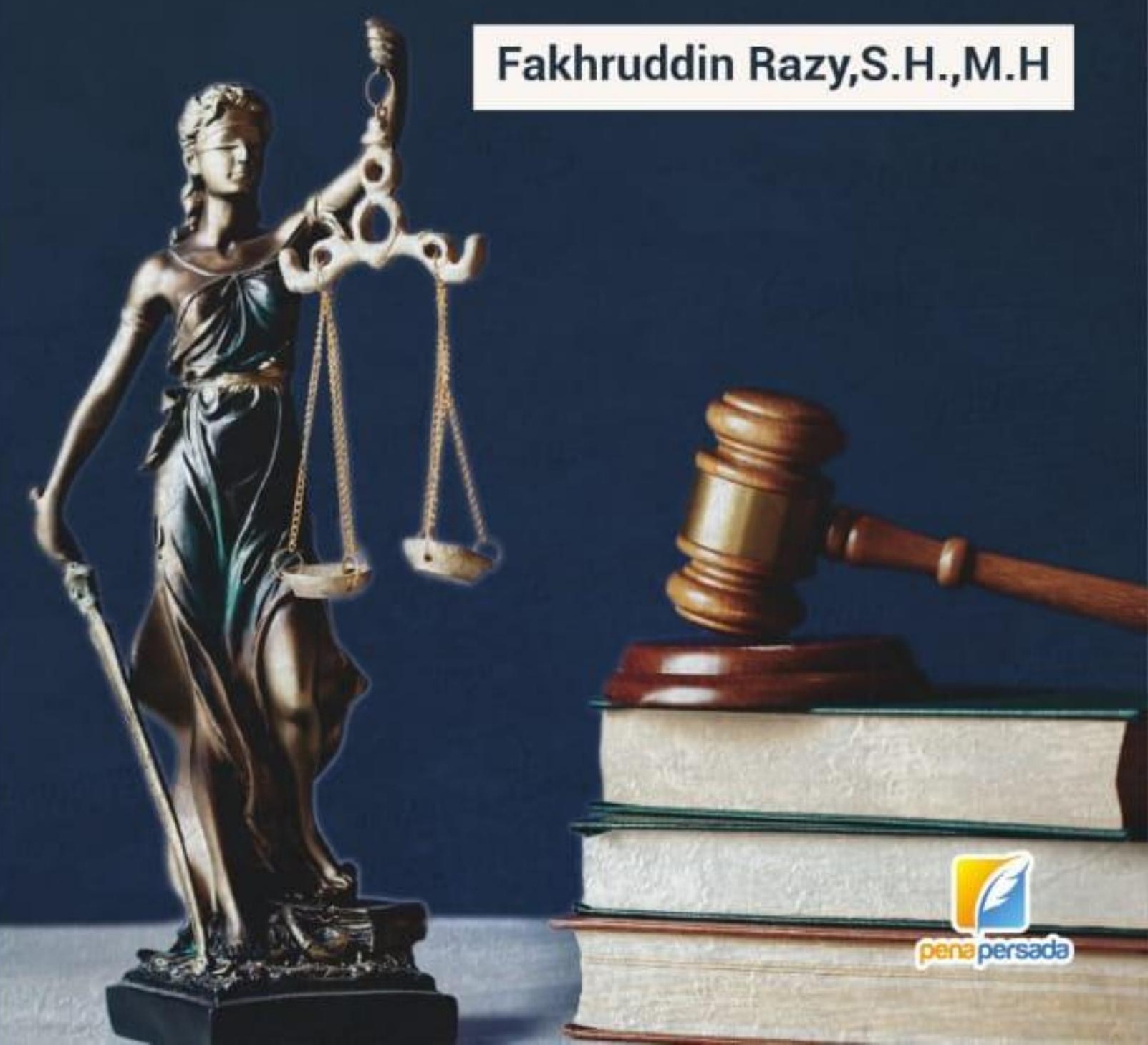




\section{BUKU AJAR \\ HUKUM ADMINISTRASI NEGARA}

FAKHRUDDIN RAZY,S.H.,M.H

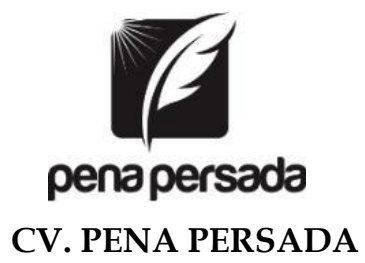




\title{
BUKU AJAR \\ HUKUM ADMINISTRASI NEGARA
}

\author{
Penulis : \\ Fakhruddin Razy,S.H.,M.H \\ ISBN : 978-623-315-049-1 \\ Design Cover : \\ Retnani Nur Briliant \\ Layout : \\ Hasnah Aulia \\ Penerbit CV. Pena Persada \\ Redaksi : \\ Tengah \\ Email : penerbit.penapersada@gmail.com \\ Website : penapersada.com \\ Phone : (0281) 7771388 \\ Anggota IKAPI \\ All right reserved \\ Cetakan pertama : 2020
}

Jl. Gerilya No. 292 Purwokerto Selatan, Kab. Banyumas Jawa

Hak cipta dilindungi oleh undang-undang.

Dilarang memperbanyak buku ini dalam bentuk dan cara apapun tanpa ijin penerbit 


\section{KATA PENGANTAR}

Puji dan syukur penulis panjatkan kepada Allah SWT atas berkat dan karunia-Nya, penulis dapat menyelesaikan buku Ajar Hukum Administrasi Negara ini dengan baik.

Adapun tujuan dari Buku Ajar ini adalah untuk memberi wawasan yang lebih baik bagi setiap pembacanya terutama bagi mahasiswa Program Studi Hukum.agar lebih memahami tentang Hukum Administrasi Negara terutama dalam hal konseptual dan teori yang dipaparkan dalam pembelajaran mata kuliah ini.

Penulis juga menyadari bahwa pembuatan buku ajar ini masih jauh dari kesempurnaan. Maka untuk itu, penulis mohon maaf atas kekurangan dalam buku ajar ini. Dan penulis juga berharap kepada pembaca atas saran dan kritk yang membangun.

Akhir kata penulis mengucapkan terima kasih atas segala bantuan dari berbagai pihak.

Banjarmasin, 7 Desember 2020

Fakhruddin Razy,S.H.,M.H. 


\section{DAFTAR ISI}

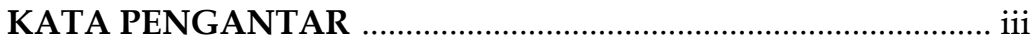

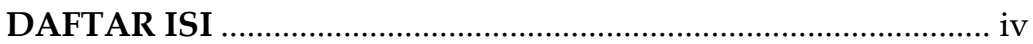

BAB I PENDAHULUAN

A. Berbagai Istilah Hukum Administrasi Negara .................... 1

B. Pengertian Hukum Administrasi Negara ............................. 2

C. Pengertian Alat Administrasi Negara, Pemerintah

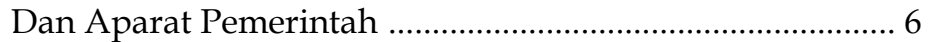

D. Ruang Lingkup Hukum Administrasi Negara .................... 8

E. Kedudukan Hukum Administrasi Negara Dalam Lapangan Hukum .................................................................. 11

F. Hubungan Antara Hukum Administrasi Negara Dan Hukum Tata Negara .......................................................... 12

BAB II SUMBER-SUMBER HUKUM ADMINISTRASI NEGARA DAN SUBYEK HUKUM ADMINISTRASI NEGARA
A. Sumber Hukum Materiil Hukum Administrasi Negara ..... 16
B. Sumber Hukum Formil Hukum Administrasi Negara ....... 17
C. Subyek Hukum Administrasi Negara ..................................... 22

BAB III KONSEP KEWENANGAN DALAM ADMINISTRASI NEGARA
A. Pengertian 28
B. Jenis-Jenis Kewenangan 29

BAB IV BENTUK-BENTUK PERBUATAN ADMINISTRASI NEGARA

A. Pengertian Perbuatan Administrasi Negara ......................... 33

B. Macam-Macam Perbuatan Alat Administrasi Negara ......... 33

C. Keputusan/Ketetapan Administrasi Negara ....................... 36

D. Syarat-Syarat Agar Keputusan/Ketetapan Menjadi Sah .... 42

E. Keputusan/Ketetapan AN harus dibuat oleh alat yang berwenang/berkuasa ................................................................ 43

F. Dalam Kehendak Alat AN yang Berkuasa Tidak Boleh Ada Kekurangan Yuridis ........................................................ 45

G. Bentuk dan Tata Cara Pembuatan Keputusan Harus Sesuai dengan Peraturan Dasarnya ...................................... 46

H. Keputusan/Ketetapan AN Harus dibuat oleh Alat Yang Berwenang/Berkuasa ........................................................... 47

I. Kekuatan Hukum Suatu Keputusan/Ketetapan .................... 48

J. Macam-Macam Keputusan/Ketetapan Administrasi Negara 51 
BAB V ASAS_ASAS UMUM PEMERINTAHAN YANG BAIK

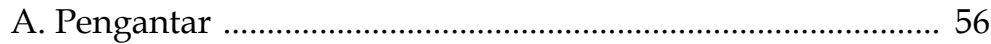

B. Jenis Asas Umum Pemerintahan Yang Baik ......................... 57

BAB VI PERADILAN TATA USAHA NEGARA

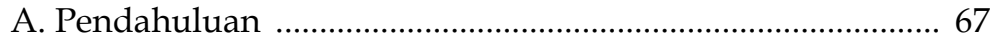

B. Tinjauan Historis Peradilan Tata Usaha Negara ................. 67

C. Negara Hukum dan PTUN …………………...................... 68

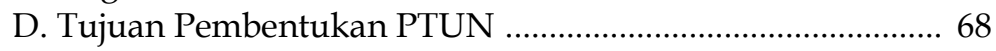

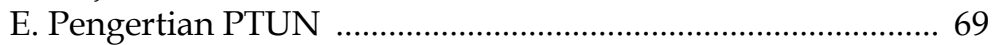

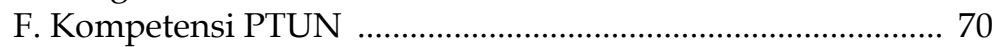

G. Asas Hukum Acara PTUN ……………………................... 70

BAB VII HUKUM KEUANGAN NEGARA

A. Pengantar ……..................................................................... 73

B. Asas Umum Pengelolaan Keuangan Negara ....................... 75

C. Ruang Lingkup Keuangan Negara ....................................... 76

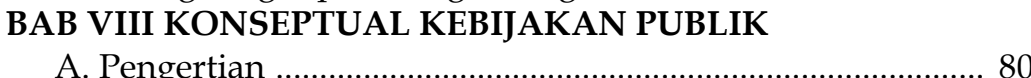

B. Ruang Lingkup Kebijakan Publik ......................................... 86

C. Arti Penting kebijakan Publik ............................................... 86

BAB IX HUKUM PERIZINAN

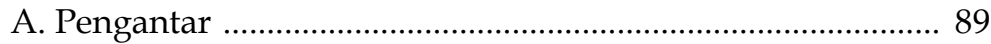

B. Pengertian Perizinan ............................................................. 90

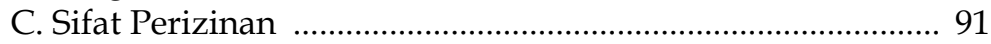

D. Unsur Perizinan ...................................................................... 92

E. Penegakan Hukum Perizinan ................................................. 93

BAB X HUKUM KEPEGAWAIAN

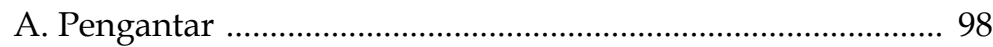

B. Dasar Hukum Kepegawaian ............................................... 98

C. Maksud dan Tujuan ................................................................ 100

D. Aspek Kewajiban dan Larangan Bagi Pegawai Negeri

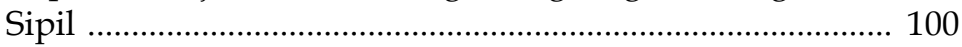

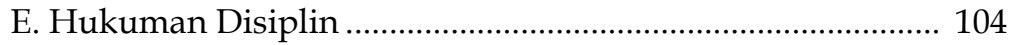




\section{BUKU AJAR \\ HUKUM ADMINISTRASI NEGARA}




\section{BAB I \\ PENDAHULUAN}

\section{A. Berbagai Istilah Hukum Administrasi Negara}

Ada berbagai istilah di dalam penyebutan Hukum Administrasi Negara yang merupakan terjemahan dari Administratiefrecht yang dikenal di Negara Belanda, Verwaltungsrecht di Jerman, Droit Administratif di Perancis, Administratif Law di negara Inggris dan Amerika. Sebagaimana kita ketahui bahwa Indonesia dahulu merupakan bekas jajahan Belanda, sehingga Hukum Administrasi Negara Indonesia merupakan terjemahan dari Administratiefrecht.

Untuk menerjemahkan Administratiefrecht dari Hukum Belanda ini para ahli hukum di Indonesia belum ada kata sepakat. Baru setelah dikeluarkannya UU No.5 tahun 1986 tentang Peradilan Tata Usaha Negara yang dikeluarkan oleh para ahli. E.Utrecht dalam bukunya "Pengantar Hukum Administrasi" , mula- mula memakai istilah Hukum Administrasi Negara Indonesia. WF Prins dalam bukunya "Inleiding in het administratiefrecht" memakai istilah Hukum Tata Usaha Negara Indonesia. Wirjono Prodjodikoro memakai istilah Hukum Tata Usaha Pemerintah. Prajudi Atmasudirdjo memakai istilah Hukum Administrasi Negara. Dalam SK Mendikbud tanggal 30 Desember 1972, No.0198/U/1972 tentang Kurikulum Minimal menggunakan istilah Hukum Tata Pemerintahan. Rapat staf dosen Fakultas-fakultas Hukum Negeri seluruh Indonesia yang diadakan pada bulan Maret 1973 di Cibulan, memakai istilah Hukum Administrasi Negara dengan tidak menutup kemungkinan menggunakan istilah lain. SK Kurikulum yang terakhir menggunakan istilah Hukum Tata Usaha Negara. 


\section{B. Pengertian Hukum Administrasi Negara}

Ada beberapa ahli yang mencoba membirikan pengertian tentang Hukum Tata Usaha Negara, diantaranya: JHP Bellafroid; Oppenheim; Logemann; E.Utrecht; dan Prajudi Atmasudirdjo.

1. JHP Bellafroid menyatakan bahwa Hukum Tata Usaha Negara/Hukum Tata Pemerintahan adalah keseluruhan aturan-aturan tentang cara bagaimana alat-alat perlengkapan pemerintahan dan badan-badan kenegaraan serta majelis-majelis pengadilan khusus yang diserahi pengadilan tata usaha negara hendaknya memenuhi tugasnya.

2. Oppenheim mengemukakan bahwa Hukum Administrasi Negara adalah suatu gabungan ketentuan-ketentuan yang mengikat badan-badan yang tinggi maupun rendah apabila badan-badan itu menggunakan wewenang yang telah diberikan kepadanya oleh HukumTata Negara. Hukum Administrai Negara menggambarkan negara dalam keadaan bergerak.

3. Logemann mengetengahkan Hukum Pemerintahan/Hukum Administrasi Negara sebagai seperangkat norma-norma yang menguji hukum istimewa yang diadakan untuk memungkinkan para pejabat (Alat Tata Usaha Negara/ Alat Administrasi Negara) melakukan tugas mereka yang khusus. Hukum Administrasi Negara tidak identik/sama dengan hukum yang mengatur pekerjaan administrasi negara, karena hukum yang mengatur pekerjaan administrasi negara sudah termasuk dalam Hukum Tata Negara.

4. De La Bascecour Caan menyatakan bahwa Hukum Administrasi Negara adalah himpunan peraturan-peraturan tertentu yang menjadi sebab maka negara berfungsi (bereaksi). Dengan demikian peraturan-peraturan itu mengatur hubungan-hubungan antara warga negara dengan pemerintahannya. Hukum Administrasi Negara terbagi atas dua bagian, yakni: Pertama, Hukum Administrasi Negara menjadi sebab maka negara berfungsi atau 
bereaksi; Kedua, Hukum Administrasi Negara mengatur hubungan antara warga negara dengan pemerintah.

5. Sir W.Ivor Jenning mengemukakan bahwa Hukum Administrasi Negara adalah hukum yang berhubungan dengan administrasi negara. Hokum ini menentukan organisasi kekuasaan dan tugas-tugas dari pejabat-pejabat administrasi.

6. R. Kranenburg memberikan definisi Hukum Administrasi Negara dengan memperbandingkannya dengan Hukum Tata Negara, meskipun hanya sekedar perlu untuk pembagian tugas. Menurutnya Hukum Administrasi Negara adalah meliputi hukum yang mengatur susnan dan wewenang khusus dari alat perlengkapan badan-badan seperti kepegawaian (termasuk mengenai pensiun) peraturan wajib militer, pengaturan mengenai pendidikan /pengajaran, peraturan mengenai jaminan sosial, peraturan mengenai perumahan, peraturan per-buruhan, peraturan jaminan orang miskin, dan sebagainya.

7. E.Utrecht mengemukakan bahwa Hukum Administrasi Negara/Hukum Pemerintahan adalah hukum yang menguji hubungan hukum istimewa yang bila diadakan akan memungkinkan para pejabat administrasi negara melakukan tugas mereka yang khusus.

8. Prajudi Atmosudirdjo merumuskan HAN sebagai “...... Hukum yang mengenai Pemerintah beserta aparatnya yang terpenting yakni Administrasi Negara" selanjutnya dikatakan bahwa "..... hukum administrasi negara mengatur wewenang, tugas, fungsi dan tingkah laku para pejabat Administrasi Negara....." bertujuan untuk menjamin adanya Administrasi Negara yang bonafit, artinya yang tertib, sopan, berlaku adil dan obyektif, jujur, efisien dan fair. Dinyatakan juga bahwa hukum administrasi negara itu merupakan hukum mengenai Administrasi Negara dan hukum hasil ciptaan Administrasi Negara, sehingga Hukum Administrasi Negara pada dasarnya dapat dibedakan dalam dua klasifikasi yakni Hukum 
Administrasi Negara heteronom dan Hukum Administrasi negara yang otonom. Hukum Administrasi Negara heteronom bersumber pada UUD, TAP MPR dan UU, hukum ini mengatur seluk beluk organisasi dan fungsi Administrasi Negara (alat tata usaha negara) dan tidak boleh dilawan, dilanggar serta tidak boleh diubah oleh Administrasi Negara. HAN heteronom ini mencakup aturan tentang:

a. Dasar-dasar dan prinsip umum administrasi negara;

b. Organisasi administrasi negara, termasuk juga pengertian dekonsentrasi dan desentralisasi;

c. Berbagai aktivitas dari administrasi negara;

d. Seluruh sarana administrasi negara;

e. Badan peradilan administrasi

Sedangkan Hukum Administrasi Negara Otonom bersumber pada keputusan pemerintah yang bersifat sebagai UU dalam arti yang luas, yurisprudensi danteori. Hukum ini merupakan hukum operasional yang diciptakan oleh pemerintah dan administrasi negara sendiri. Oleh karena itu dapat diubah oleh pemerintah/administrasi negara (alat tata usaha negara) setiap waktu bila perlu tidak melanggar asas kepastian hukum, dan asas kepentingan umum.

9. Prajudi Atmosudirdjo mengemukakan bahwa pemerintah dijalankan oleh penguasa eksekutif beserta aparatnya, sedangkan administrasi negara dijalankan oleh penguasa administrasi beserta aparatnya. Oleh karena itu Indonesia berdasarkan ketentuan UUD 1945 kekuasaan eksekutif dan administratif berada dalam satu tangan yakni Presiden, maka pengertian HAN yang luas terdiri atas lima (5) unsur, yaitu:

a. HTP : hukum eksekutif atau hukum tata pelaksanaan UU, yang menyangkut pengendalian penggunaan kekuasaan public (kekuasaan yang berasal dari kedaulatan rakyat). 
b. HTUN : hukum mengenai surat menyurat, rahasia dinas dan jabatan, registrasi, kearsipan dan dokumentasi, legalisasi, pelaporan dan statistic, tata cara penyusunan dan penyimpanan berita acara, pencatatan sipil, pencatatan NTR, publikasi, penerangan dan penerbitanpenerbitan negara. Atau sering dikenal dengan Hukum Birokrasi.

c. Hukum Administrasi Negara dalam arti sempit : hukum tata pengurusan rumah tangga negara baik intern maupun ekstern.

d. Hukum Administrasi Pembangunan : mengatur campur tangan pemerintah dalam kehidupan dan penghidupan masyarakat untuk mengarahkan kepada perubahan yang telah direncanakan.

e. Hukum Administrasi Lingkungan : mengatur campur tangan pemerintah dalam pengelolaan lingkungan.

10. Sjachran Basah mengemukakan bahwa sebagai inti hakekat Hukum Administrasi Negara adalah: Pertama, memungkinkan administrasi negara untuk menjalankan fungsinya; Kedua, melindungi keluarga terhadap sikap tindak (perbuatan) administrasi negara dan juga melindungi administrasi negara itu sendiri. Selanjutnya dikatakan bahwa melindungi sikap tindak administrasi negara di satu pihak dan warga negara di lain pihak, pada dasarnya menciptakan kepastian hukum yaitu segala sikap tindak administrasi negara harus senantiasa memperhatikan batasbatas, baik batas atas maupun bawah. Batas asas, dimaksudkan taat asas yaitu bahwa sikap tindak administrasi negara dalam mewujudkan tugas kekuasaannya, di antaranya mengeluarkan keputusan, maka putusan-putusan itu apabila lebih rendah tidak boleh bertentangan dengan peraturanperundang-undangan yang lebih tinggi. Batas bawah, maksudnya bahwa peraturan yang dibuat tidak boleh melanggar hak dan kewajiban asasi warga negara. 
Kesimpulan: dapat dikatakan secara ringkas bahwa yang dimaksudkan dengan Hukum Administrasi negara adalah hukum yang mengatur dan mengikat alat administrasi negara dalam menjalankan wewenang yang menjadi tugasnya selaku alat administrasi negara dalam melayani warga negara harus senantiasa memperhatikan kepentingan warga negara. HAN sangat penting dan dibutuhkan dalam penyelenggaraan kekuasaan negara oleh administrasi negara. Keberadaan hukum administrasi negara berperan mengatur wewenang, tugas dan fungsi administrasi negara, disamping itu juga berperan untuk membatasi kekuasaan yang diselenggarakan oleh administrasi negara.

\section{Pengertian Alat Administrasi Negara, Pemerintah Dan Aparat Pemerintah}

Victor Situmorang dalam bukunya "Dasar-dasar Hukum Administrasi Negara" meninjau pengertian Administrasi Negara/Tata Usaha Negara dan Pemerintah dari dua (2) segi :

1. Tinjauan dari para penganut teori residu yang terkena pengaruh teori

Trias Politika (dengan tokoh Van Vollen Hoven), menyatakan bahwa administrasi negara/tata usaha negara adalah gabungan jabatan-jabatan, berupa aparat/alat administrasi yang dibawah pimpinan pemerintah melaksanakan sebagian pekerjaan pemerintah (tugas pemerintah) berupa fungsi administrasi yang tidak ditugaskan kepada badan-badan pengadilan, badan legislatif dan badan-badan pemerintah dari persekutuan hukum yang lebih rendah dari persekutuan negara. Persekutuan-persekutuan hukum yang lebih rendah dari negara adalah daerah yang masin-masing diberi kekuasaan untuk memerintah sendiri daerahnya atas inisiatif sendiri atau berdasarkan suatu delegasi kekuasaan dari pemerintah pusat (dulu dikenal dengan daerah swatantra tingkat I,II,III serta Daerah Istimewa).

2. Tanpa pengaruh teori Trias Politika, dikemukakan oleh AM Donner bahwa Administrasi negara adalah badan yang 
melaksanakan/menyelenggarakan tujuan negara. Pendapat ini dikemukakan oleh Donner karena dia meninjau dari segi fungsi negara yakni sebagai penentu tujuan negara.

Prajudi Atmosudirdjo mengemukakan ada tiga (3) arti daripada Administrasi Negara, yaitu :

1. Sebagai aparatur negara, aparatur pemerintah, atau sebagai institusi politik;

2. Sebagai "fungsi" atau sebagai aktivitas melayani atau sebagai kegiatan "pemerintah operasional; dan

3. Sebagai proses teknis penyelenggaraan UU.

WF. Prins membedakan pemerintah dalam arti luas dan pemerintah dalam arti sempit. Pemerintah dalam arti luas : seluruh kekuasaan yang ada dalam suatu negara (legislative, eksekutif, yudikatif, dan polisionil), jadi identik dengan negara. Pemerintah dalam arti sempit : kekuasaan yang mempunyai tugas khusus, yakni melaksanakan tujuan dari peraturan perundangan (eksekutif).

Muchsan menyatakan bahwa aparat pemerintah (dalam arti sempit) adalah para pejabat yang melaksanakan kekuasaan eksekutif. Di negara Indonesia berdasarkanketentuan UUD1945 bentuk dari aparat pemerintah dalam arti sempit adalah Presiden sebagai Kepala Pemerintahan dengan para Mentri sebagai pembantu Presiden beserta jabatan-jabatan bawahan lainnya.

Philipus M.Hadjon dkk mengemukakan bahwa pemerintahan dapat difahami melalui dua pengertian : di satu pihak dalam arti "fungsi pemerintah" (kegiatan memerintah), di lain pihak dalam arti "organisasi pemerintah" (kumpulan dari kesatuan-kesatuan pemerintah). Fungsi dari pemerintah itu dapat ditentukan sedikit banyak dengan menempatkannya dalam hubungan dengan fungsi perundangundangan dan peradilan. Pemerintahan dapat dirumuskan secara negatip sebagai segala macam kegiatan penguasa yang tidak dapat disebutkan sebagai suatu kegiatan perundang- 
undangan atau peradilan. Perbedaan antaraperundangundangan, peradilan, dan pemerintah ini mengingatkan kita pada Trias Politika. Dalam ajaran yang sudah lama ini dianut pandangan tentang adanya suatu pemisahan diantara kekuasaan pembuat undang-undang kehakiman dan pihak pelaksana (eksekutif).

Dewasa ini "pemerintahan" ini tidak sama dengan "kekuasaan eksekutif". Banyak jenis pemerintahan yang tidak dapat dipandang sebagai pelaksanaan dari undang- undang seperti pemberian subsidi tertentu, atau tugas melaksanakan pekerjaan umum. Bagaimanapun di kalangan para ahli hukum administrasi negara di tah un-tahun akhir ini telah berkembang perhatian yang luas terhadap keputusankeputusan yang bersifat umum, yakni rencana-rencana, peraturan-peraturan kebijaksanaan, juga peraturan pemberian kuasa (wewenang). Tetapi perhatian itu lebih banyak terarah pada suatu pendekatan aturan-aturan yang sah dari sudut pandang hukum administrasi, bukan pada suatu pendekatan dari sudut hukum politik tata negara.

\section{Ruang Lingkup Hukum Administrasi Negara}

Adapun ruang lingkup dari HukumAdministrasi Negara adalah bertalian erat dengan tugas dan wewenang lembaga negara (administrasi negara) baik di tingkat pusat maupun daerah, perhubungan kekuasaan antar lenbaga negara (administrasi negara), dan antara lembaga negara dengan warga masyarakat (warga negara) serta memberikan jaminan perlindungan hukum kepada keduanya, yakni kepada warga masyarakat dan administrasi negar itu sendiri. Dalam perkembangan sekarang ini dengan kecenderungan negara turut campur tangan dalam berbagai aspek kehidupan masyarakat, maka peranan Hukum Administrasi Negara (HAN) menjadi luas dan kompleks. Kompleksitas ini akan membuat luas dan complicated dalam menentukan rumusan ruang lingkup HAN. 
Secara historis pada awalnya tugas negara masih sangat sederhana, yakni sebagai penjaga malam (natchwachter staad) yang hanya menjaga ketertiban, keamanan, dan keteraturan serta ketentraman masyarakat. Oleh karenanya negara hanya sekedar penjaga dan pengatur lalu lintas kehidupan masyarakat agar tidak terjadi benturan-benturan, baik menyangkut kepentingan hak dan kewajiban, kebebasan dan kemerdekaan, dan atau benturan-benturan dalam kehidupan masyarakat lainnya. Apabila hal itu sudah tercapai, tugas negara telah selesai dan sempurna. Pada suasana yang demikian itu HAN tidak berkembang dan bahkan statis.

Keadaan seperti ini tidak akan dijumpai saat ini, baik di Indonesia maupun di negara-negara belahan dunia lainnya. Dalam batas-batas tertentu (sekecil, sesederhana dan seotoriter apapun) tidak ada lagi negara yang tidak turut ambil bagian dalam kehidupan warga negaranya. Untuk menghindarkan kemungkinan terjadinya hal tersebut, maka perlu dibentuk hukum yang mengatur pemberian jaminan dan perlindungan bagi warga negara (masyarakat) apabila sewaktu- waktu tindakan administrasi negara menimbulkan keraguan pada warga masyarakat dan bagi administrasi negara sendiri. Untuk mewujudkan cita-cita itu tepatlah apa yang dikemukakan oleh Sjachran Basah bahwa fungsi hukum secara klasik perlu ditambah dengan fungsi-fungsi lainnya untuk menciptakan hukum sebagai sarana pembaharuan masyarakat. Oleh karena itu hukum harus tidak dipandang sebagai kaidah semata-mata, akan tetapi juga sebagai sarana pembangunan, yaitu berfungsi sebagai pengarah dan jalan tempat berpijak kegiatan pembangunan untuk mencapai tujuan kehidupan bernegara. Di samping itu sebagai sarana pembaharuan masyarakat hukum harus juga mampu memberi motivasi cara berpikir masyarakat kearah yang lebih maju, tidak terpaku kepada pemikiran yang konservatif dengan tetap memperhatikan factor- faktor sosiologis, antropologis, dan kebudayaan masyarakat. Namun demikian seperti apa yang dikemukakan oleh Mochtar Kusumaatmaja hukum tetap harus 
memperhatikan, memelihara dan mempertahankan ketertiban sebagai fungsi klasik dari hukum.

Mengenai ruang lingkup yang dipelajari dalam studi Hukum Administrasi Negara, Prajudi Atmosudirdjo mengemukakan ada enam ruang lingkup yang dipelajari dalam HAN yaitu meliputi :

1. Hukum tentang dasar-dasar dan prinsip-prinsip umum dari administrasi negara;

2. Hukum tentang organisasi negara;

3. Hukum tentang aktivitas-aktivitas dari administrasi negara, terutama yang bersifat yuridis;

4. Hukum tentang sarana-sarana dari administrasi negara terutama mengenai kepegawaian negara dan keuangan negara;

5. Hukum administrasi pemerintah daerah dan Wilayah, yang dibagi menjadi:

a. Hukum Administrasi Kepegawaian;

b. Hukum Administrasi Keuangan;

c. Hukum Administrasi Materiil;

d. Hukum Administrasi Perusahaan Negara.

6. Hukum tentang Peradilan Administrasi Negara.

Kusumadi Pudjosewojo, membagi bidang-bidang pokok Hukum Administrasi Negara sebagai berikut :

1. Hukum Tata Pemerintahan;

2. Hukum Tata Keuangan termasuk Hukum Pajak;

3. Hukum Hubungan Luar Negri;

4. Hukum Pertahanan dan Keamanan Umum.

Walther Burekhardt menyebutkan bidang-bidang pokok bagian dari Hukum Administrasi Negara, yaitu :

1. Hukum Kepolisian, berisi aturan-aturan hukum yang mengandung norma untuk bertingkah laku, bersifat larangan/pengingkaran dan mengadakan pembatasanpembatasan tertentu terhadap kebebasan seseorang guna kepentingan keamanan umum; 
2. Hukum Perlembagaan, yaitu aturan-aturan hukum yang ditujukan kepada panguasa untuk menyelenggarakan perkembangan rakyat dan pembangunan dalam lapangan kebudayaan, kesenian, Ilmu Pengetahuan, kerohanian dan kejasmanian, kemasyarakatan dan lain-lain (pendidikan dan pengajaran di sekolah-sekolah, perpustakaan, tentang rumah sakit). Dengan meluasnya bidang-bidang kebebasan bergeraknya perseorangan maka penguasa wajib mengatur hubungan-hubungan hukum individu-individu tersebut berdasarkan tugasnya yakni menyelenggarakan kepentingan umum;

3. Hukum Keuangan, yaitu aturan-aturan hukum tentang upaya menyediakan perbekalan guna melaksanakan tugastugas penguasa. Misalnya, aturan tentang pajak, bea dan cukai, peminjaman uang bagi negara dan lain- lainnya.

\section{E. Kedudukan Hukum Administrasi Negara Dalam Lapangan Hukum}

Hukum Administrasi Negara merupakan salah satu cabang/bagian dari ilmu hukum yang khusus. HAN merupakan ilmu hukum yang tidak statis, akan tetapi berkembang sesuai dengan perkembangan kebutuhan dalam masyarakat. Di dalam ilmu hukum publik, mula-mula HAN merupakan bagian dari HTN, kuliah- kuliah HAN ditempelkan dalam HTN, akan tetapi karena timbulnya Welfare State, negara hukum modern yang mengutamakan kesejahteraan rakyat pada akhir abad 19 dan permulaan abad20 (antara tahun (1946-1948) diadakan pemisahan antara HAN dengan HTN. HAN berkembang dengan pesat, kemudian HAN diakui merupakan bagian tersendiri dari hukum publik dan sebagian ada pada hukum privat.

Philipus M. Hadjon dkk mengemukakan bahwa hukum administrasi materiil terletak diantara hukum privat dan hukum pidana (publik). Hukum pidana berisi normanorma yang begitu penting (esensial) bagi kehidupan masyarakat sehingga penegakan norma-norma tersebut tidak diserahkan pada pihak partikelir tetapi harus dilakukan oleh 
penguasa. Hukum privat berisi norma-norma yang penegakannya dapat diserahkan pada pihak partikelir. Diantara bidang hukum itu terletak hukum administrasi. Oleh karenanya HAN dapat dikatakan sebagai "hukum antara".

\section{F. Hubungan Antara Hukum Administrasi Negara Dan Hukum Tata Negara}

Ada dua golongan pendapat mengenai hubungan antara HAN dengan HTN. Golongan pertama, menyatakan ada perbedaan yuridis prinsipiil antara HAN dengan HTN. Golongan kedua menyatakan tidak ada perbedaan yuridis prinsipiil antara HAN dengan HTN. Para ahli yang berpendapat bahwa ada perbedaan yuridis prinsipiil antara HAN dan HTN adalah Oppenheim, Van Vollenhoven dan Logeman. Sedangkan pendapat kedua yang menyatakan tidak ada perbedaan yuridis prinsipiil antara HAN dan HTN diikuti oleh Kranenburg, Prins, dan Prajudi Atmosudirdjo.

Oppenheim, menyatakan bahwa yang dipersoalkan HTN adalah Negara dalam keadaan berhenti sedangkan HAN adalah peraturan-peraturan hukum mengenai negara dalam keadaan bergerak. HTN merupakan kumpulan peraturanperaturan hukum yang membentuk alat-alat perlengkapan negara dan memberikan kepadanya wewenang yang membagibagikan tugas pekerjaan dari pemerintah modern antara bebeeapa alat perlengkapan negara di tingkat tinggi dan tingkat rendah. Sedangkan HAN adalah sekumpulan peraturan-peraturan hukum yang mengikat alat-alat perlengkapan yang tinggi maupun yang rendah dalam menggunakan wewenangnya yang telah diberikan/ditetapkan dalam HTN.

Van Vollenhoven menyatakan bahwa yang termasuk di dalam HAN, adalah semua peraturan hukum nasional sesudah dikurang HTN materiil, hukum perdata materiil dan hukum pidana materiil. Hubungan antara HTN dengan HAN, yaitu bahwa badan-badan kenegaraan memperoleh wewenang dari HTN dan badan-badan kenegaraan itu menggunakan wewenangnya harus berdasarkan atau sesuai dengan HAN. 
Logeman mengemukakan bahwa HTN merupakan suatu pelajaran tentang kompetensi, sedangkan HAN/HTP merupakan suatu pelajaran tentang perhubunganperhubungan hukum istimewa. Menurutnya HTN mempelajari

1. Jabatan-jabatan apa yang ada dalam susunan suatu negara;

2. Siapa yang mengadakan jabatan tersebut;

3. Dengan cara bagaimana jabatan-jabatan itu ditempati oleh pejabat;

4. Fungsi/lapangan kerja dari jabatan-jabatan itu;

5. Kekuasaan hukum dari jabatan-jabatan itu;

6. Hubungan antara masing-masing jabatan;

7. Dalam batas-batas manakah organ-organ kenegaraan dapat melakukan tugasnya.

Sedangkan yang dipelajari dalam HAN/HTP yaitu sifat, bentuk dan akibat hukum yang timbul karena perbuatan hukum istimewa yang dilakukan oleh para pejabat dalam menjalankan tugasnya.

Kranenburg, Prins dan Prajudi Atmosudirdjo menyatakan bahwa antara HAN dengan HTN tidak ada perbedaan yuridis prinsipiil, perbedaan yang ada hanya pada titik berat/fokus pembahasan. HTN fokusnya adalah hukum rangka dasar dari negara sebagai keseluruhan, sedangkan HAN fokusnya merupakan bagian khusus dari HTN.

Kranenburg menyatakan bahwa kalau di dalam praktek ada perbedaan, hanya karena untuk mencapai kemanfaatan dalam penyelidikan. Menurutnya yang digolongkan dalam HTN adalah peraturan-peraturan yang mengatur struktur umum dari suatu pemerintahan negara, misalnya UUD dan UU organic (UU yang mengatur daerah-daerah otonom), HAN berisi UU dan peraturan- peraturan khusus misalnya : hukum kepegawaian.

Prins mengemukakan bahwa HTN mempelajari hal-hal yang fundamental yang merupakan dasar-dasar dari negara dan langsung menyangkut tiap-tiap warga negara, sedangkan HAN menitikberatkan pada hal-hal yang teknis saja, yang 